\title{
Zinc Finger Protein 36, C3H1 Type-Like 2
}

National Cancer Institute

\section{Source}

National Cancer Institute. Zinc Finger Protein 36, C3H1 Type-Like 2. NCI Thesaurus. Code C21456.

Zinc finger protein $36, \mathrm{C} 3 \mathrm{H} 1$ type-like $2(494 \mathrm{aa}, \sim 51 \mathrm{kDa})$ is encoded by the human ZFP36L2 gene. This protein is involved in the regulation of mRNA stability. 